\title{
Peran Kualitas Auditor dalam Meningkatkan Relevansi Nilai di dalam Earnings dan Book Value of Equity
}

\author{
Christopher Bryan, Daniel Firmansyah, Rinanigsih, Johan Yanto* \\ Sekolah Bisnis dan Ekonomi - Universitas Prasetiya Mulya \\ BSD City Kavling Edutown I.1 , Jl. BSD Raya Utama, BSD City, Tangerang 15339
}

Keywords:

Relevance value, audit quality, earnings, book value of equity, stock return.

\section{Kaca Kunci: \\ Relevansi nilai, kualitas audit, earning, book value of equity, return saham}

\section{Corresponding author:}

johan.yanto@pmbs.ac.id

\begin{abstract}
The purpose of this research is to see the difference of value relevance contained in earnings and book value of equity to stock return on companies audited by different audit quality. Audit quality measurements are measured using auditor size and auditor specialization. The sample used in the study is a company listed on the Indonesia Stock Exchange between the periods 2006 to 2015, the company engaged in non-financial, possess the completeness of the financial report during period of study, and has no negative book value of equity. The study used paired t-test for each subsample. The results of this study indicate that there is no difference in the value relevance of the audited companies with different audit quality.

\section{Sari Pati}

Tujuan dari penelitian ini adalah untuk melihat perbedaan relevansi nilai yang terdapat di dalam earning dan book value of equity terhadap return saham pada perusahaan yang diaudit oleh kualitas audit yang berbeda. Pengukuran kualitas audit diukur dengan menggunakan ukuran auditor dan spesialisasi auditor. Sampel yang digunakan di dalam pene litian adalah perusahaan yang terdaftar pada Bursa Efek Indonesia antara periode 2006 sampai 2015, perusahaan yang bergerak pada bidang non keuangan, memiliki kelengkapan laporan keuangan selama periode pene litian, dan tidak memiliki nilai buku ekuitas negatif. Penelitian menggunakan uji beda untuk masingmasing subsampel. Hasil penelitian ini mengindikasikan bahwa tidak terdapatnya perbedaan relevansi nilai pada perusahaan yang diaudit dengan kualitas audit yang berbeda.
\end{abstract}




\section{Pendahuluan}

Laporan keuangan merupakan salah satu instrumen penting di dalam dunia perekonomian. Laporan keuangan merupakan gambaran akan kinerja maupun posisi suatu perusahaan di dalam industri atau pasar. Candrapala (2013) dalam penelitiannya mengatakan bahwa tujuan utama dari financial statement adalah untuk kebenaran dan kewajaran terhadap pandangan akan kinerja perusahaan dan posisi keuangan perusahaan. Sehingga banyak pihak yang mengandalkan informasi yang terdapat di dalam laporan keuangan di dalam pasar atau industri. Dengan kata lain laporan keuangan merupakan salah satu alat yang dapat digunakan bagi para pelaku pasar untuk melakukan pengambilan keputusan dalam kebijakan mereka. Dengan tingginya ketergantungan para pelaku pasar terhadap laporan keuangan perusahaan, maka data yang ditampilkan harus memiliki kualitas data yang andal dan dapat dipercaya.

Dalam penelitian yang dilakukan Barth, Beaver, dan Landman (2001) menyatakan bahwa perusahaan yang memiliki pelaporan keuangan yang memenuhi standar yang ditentukan memiliki nilai valuasi dan nilai ekuitas yang tinggi atau semakin tergambarkan di dalam harga saham perusahaan. Maka dari itu, guna mencapai tujuan tersebut diperlukan peranan auditor dalam memastikan akan ketepatan data tersebut. Sehingga dapat meminimalisir informasi asimetri di dalam laporan keuangan yang merupakan instrumen penting bagi pelaku pasar (Chang, Dasgupta \& Hillary, 2009).

Auditor memiliki peranan yang penting dalam menjamin informasi yang diberikan perusahaan kepada pihak eksternal (Chang et al., 2009). Dengan demikian diharapkan pula semakin tinggi kualitas auditor dapat meminimalisir informasi asimetri, sehingga laporan keuangan dapat menggambarkan nilai buku dari perusahaan tersebut dengan tepat dan akurat. Menurut Watts dan Zimmerman (1986) cara mengetahui adanya informasi asimetri adalah ketika ada banyaknya informasi mengenai kemungkinan transaksi yang beragam antara satu grup investor dengan grup yang lainnya. Almutairi, Dunn, dan Skantz (2009) juga menyatakan salah satu karakteristik dari informasi asimetri adalah sejauh mana manajer mengetahui informasi tentang perusahaan melebihi para investor. Penelitian lain yang dilakukan oleh Behn, Choi, dan Kang (2008) menemukan bahwa 
kualitas audit yang dihasilkan oleh big 5 dan auditor non big 5 terspesialisasi berhubungan dengan perkiraan performa yang lebih baik oleh para analis.

Informasi keuangan dapat dikatakan memiliki relevansi nilai, jika angka di dalam laporan keuangan perusahaan dapat menggambarkan keadaan dari nilai perusahaan yang sekarang (Beisland, 2009). Dengan memiliki informasi yang lebih relevan pada informasi dari laporan keuangan dapat menggambarkan keadaan sesungguhnya dari perusahaan tersebut. Maka dengan itu diharapkan dapat memengaruhi harga saham yang dimiliki perusahaan, baik meningkatkan harga saham tersebut atau menurunkan harga saham. Menurut Candrapala (2013) jika tidak ada hubungan antara nilai perusahaan dan angka di dalam laporan keuangan, maka laporan tersebut tidak memiliki relevansi nilai.

Menurut Chang et al. (2009) kualitas audit yang lebih tinggi dapat menurunkan informasi asimetri akan pendapatan perusahaan di masa depan. Hakim dan Omri (2010) menyatakan bahwa auditor menyediakan verifikasi independen akan laporan yang disiapkan oleh manajer dan dapat mendeteksi dan mengungkap salah saji yang ada di dalam laporan keuangan. Hakim dan Omri (1986) juga menyatakan bahwa kualitas audit dapat mengetahui adanya informasi asimetri diantara trader.

Seperti yang dikatakan Jensen dan Meckling (1976); Watts dan Zimmerman (1982), sebagaimana yang dikutip oleh Lee dan Lee (2013) menyatakan bahwa auditor memiliki peran sebagai pengikat dan pengawasan yang dapat mengurangi biaya keagensian yang diakibatkan oleh informasi asimetri. Lee dan Lee (2013) menyatakan bahwa KAP big 4 menyediakan kualitas audit yang lebih tinggi, dengan dapat mendeteksi kemungkinan adanya salah saji dan kecurangan di dalam laporan keuangan oleh manajemen. Pemilihan KAP Big 4 sendiri dikarenakan penelitian-penelitian tersebut, juga karena KAP Big 8 dianggap memiliki kualitas audit yang lebih tinggi dibandingkan dengan KAP nonBig 8 (Teoh \& Wong, 1993). Selain itu penelitian akan spesialisasi KAP (Balsam, S., Krishnan, J., \& Yang J. S., 2003) juga membuktikan bahwa KAP dengan spesialisasi tertentu memiliki tingkat kualitas audit lebih tinggi dibandingkan dengan yang tidak. Hidayat (2012) menyatakan bahwa kualitas auditor yang diukur dengan menggunakan brand KAP, yaitu KAP big 4 memiliki pengaruh yang signifikan dalam meningkatkan relevansi nilai atas nilai wajar.Namun 
Herusetya (2009) di dalam penelitiannya di Indonesia menyatakan bahwa auditor dengan spesialisasi audit dan brand name yang lebih baik (Big 4) belum dapat membuktikan secara konsisten dalam meningkatkan kualitas laba dari suatu perusahaan.

Penelitian Chang et al. (2009), Balsam et al. (2003) dan Behn et al. (2008) menemukan bahwa kualitas auditor yang lebih baik dapat memberikan laporan keuangan yang lebih terpercaya bagi para pengguna terutama dalam nilai buku dan pendapatan perusahaan. Penelitian ini merupakan replikasi dari penelitian Lee dan Lee (2013) yang digunakan sebagai acuan dalam melakukan penelitian. Namun terdapat perbedaan dalam penelitian ini yaitu, dalam penelitian ini ditambahkan spesialisasi auditor sebagai salah satu pengukur tingkat kualitas audit dan pengujian dilakukan berdasarkan subsampel. Maka penelitian ini ingin menguji apakah terdapat perbedaan relevansi nilai earnings dan book value of equity terhadap harga saham pada perusahaan yang diaudit oleh KAP big 4 dengan perusahaan yang diaudit oleh KAP non big 4?; dan apakah terdapat perbedaan relevansi nilai earnings dan book value of equity terhadap harga saham pada perusahaan yang diaudit oleh KAP terspesialisasi dengan perusahaan yang diaudit oleh KAP tidak terspesialisasi?

\section{Landasan Teori dan Pengembangan Hipotesis}

\section{Agency Problem dan Assimetric Information}

Adanya perbedaan kepentingan antara agent dan principle dalam perusahaan dapat memunculkan agency probelm (Jensen \& Meckling, 1976). Dengan memiliki kepentingan masingmasing maka tidak dapat dipungkiri akan adanya penutupan informas i yang berikan oleh salah satu pihak. Sehingga dengan adanya penutupan akan informasi ini dapat menimbulkan asymmetric information. Asymmetric information (Worldbank, 2003) merupakan keadaan di mana adanya beberapa agen di dalam pasar memiliki informasi sementara ada agen lain yang tidak memiliki informasi tersebut. Dengan adanya asymmetric information, para pelaku pasar dapat melakukan decision making yang salah atau keliru. Sehingga banyak dari pelaku pasar yang berusaha meminimalisir keberadaan asymmetric information di dalam pasar terutama di dalam laporan keuangan. 


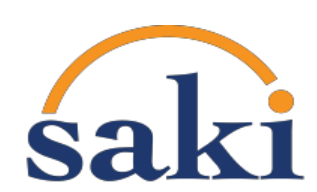

Audit atas laporan keuangan diperlukan untuk memastikan bahwa laporan keuangan yang merupakan instrumen dalam menggambarkan kinerja suatu perusahaan bebas dari asymmetric information. Kualitas audit dapat diukur menggunakan ukuran auditor Big 4 dan Non Big 4, selain itu kualitas audit juga dapat diukur dengan menggunakan faktor lain, yaitu spesialisasi audit. Dalam penelitian terdahulu yang dilakukan oleh beberapa peneliti (Craswell, Francis, \& Taylor, 1995 sebagaimana yang dikutip dalam Balsam, 2003) menyatakan bahwa selain dengan brand name, spesialisasi audit yang dimiliki oleh auditor memiliki hubungan positif terhadap tingkat kredibilitas yang ditawarkan oleh auditor tersebut.

Selain dengan menggunakan ukuran big 4 dan non big 4 serta spesialisasi audit dalam menentukan kualitas audit, audit tenur juga dapat dijadikan tolak ukur untuk mengukur tingkat kualitas audit yang diberikan oleh auditor kepada suatau perusahaan. Dalam penelitian yang dilakukan oleh Carey dan Simnett (2006) menyatakan bahwa panjangnya suatu tenur suatu auditor terhadap perusahaan memiliki kemerosotan akan kualitas audit yang dihasilkan oleh auditor. Dengan semakin lamanya tenur audit dianggap akan membuat independensi dari auditor akan berkurang yang di mana akan berdampak kepada penilaian di dalam proses audit (Dopuch, King, \& Schwartz, 2003). Selain itu Chi dan Huang (2005) juga menyatakan bahwa adanya kualitas laba yang lebih rendah yang terjadi pada di awal tahun tenur audit dan di kemudian tahun tenur audit.

Pada penelitian yang dilakukan oleh Lee dan Lee (2013) menyatakan bahwa pendapatan dan nilai buku ekuitas perusahaan memiliki relevansi nilai yang lebih tinggi jika diaudit dengan KAP Big 4 dibandingkan dengan KAP Non Big 4. Pada penelitian tersebut Lee dan Lee (2013) menggunakan EPS sebagai proksi untuk earning (pendapatan) serta nilai buku ekuitas. Sementara untuk harga saham digunakan stock return dan stock price sebagai proksi. Stock price yang digunakan adalah harga saham pada hari penutupan tahun kalender. Sampel yang digunakan adalah perusahaan yang terdaftar dalam bursa efek Taiwan pada periode 1996 sampai dengan 2009 dengan kriteria perusahaan tidak memiliki nilai buku ekuitas negatif dan tidak memiliki pendapatan yang negatif.

\section{Pengembangan Hipotesis}


Perbedaan Relevansi Nilai Earnings \& Book Value of Equity Terhadap Harga Saham Pada Perusahaan yang Diaudit Oleh KAP Big 4 dan KAP Non Big 4

Suatu informasi akuntansi yang berkualitas harus relevan, dapat diandalkan dan dipercaya. Informasi yang relevan baru dapat dikatakan bermanfaat apabila nilainya dapat diandalkan. Menurut Watts dan Zimmerman (1986, sebagaimana yang dikutip oleh Hidayat, 2012) dalam penelitian mereka menyatakan bahwa kepercayaan atas laporan keuangan perusahaan bergantung kepada kecakapan auditor dan independensi auditor. Hal ini menjadikan kualitas auditor menentukan keandalan dari laporan keuangan. Banyak penelitian mengukur kualitas audit dengan ukuran Kantor Akuntan Publik (KAP). Becker, DeFond, Jiambalvo, \& Subramanyam (1998) menyatakan bahwa proses audit mengurangi asimetris informasi yang ada di antara manager dan pemangku kepentingan perusahaan dengan memperbolehkan pihak luar memverifikasi kebenaran laporan keuangan.

Sehubungan dengan relevansi informasi akuntansi, pendapatan yang diaudit big 4 memiliki nilai prediktif yang lebih tinggi dibandingkan yang diaudit oleh non-big 4. Behn et al. (2008, sebagaimana yang dikutip oleh Lee \& Lee, 2013) menyatakan bahwa auditor Big 5 memberikan analisa perkiraan laba lebih akurat. Ukuran KAP berpengaruh terhadap relevansi nilai atas laporan keuangan, maka diandaikan bahwa, nilai relevansi laba diaudit oleh KAP big 4 lebih tinggi daripada yang diaudit oleh non big 4 .

Selain pada pendapatan yang memiliki relevansi nilai pada harga saham, dalam hasil penelitian yang dilakukan Lee dan Lee (2013) dengan menggunakan sampel perusahaan yang terdaftar pada bursa di Taiwan, hasil menunjukkan bahwa perusahaan yang diaudit dengan KAP big 4 memiliki relevansi nilai pada nilai buku dari ekuitas perusahaan terhadap harga saham. Informasi akuntansi, seperti earning dan book value, memiliki korelasi signifikan dengan harga saham atau perubahan pada harga saham tersebut. Maka dari itu kualitas audit juga dikatakan dapat memiliki relevansi nilai terhadap harga saham perusahaan.

Dengan adanya kualitas audit yang lebih baik (Big 4) yang diterima oleh perusahaan, maka diharapkan informasi yang ditampilkan jauh lebih relevan dan lebih andal. Pada penelitian yang 
dilakukan oleh Barth et. al. (2001) menemukan bahwa laporan keuangan yang memenuhi standar memiliki relevansi nilai terhadap ekuitas dan valuasi perusahaan. Selain itu Chang et al. (2009) menyatakan bahwa kualitas audit memengaruhi pengambilan keputusan akan financing decision yang akan berdampak pada capital market perusahaan. Berdasarkan penelitian terdahulu tersebut, maka dapat diambil hipotesis sebagai berikut:

$\mathbf{H}_{\mathbf{1}}$ : Terdapat Perbedaan Relevansi Nilai Earnings dan Book Value of Equity pada Perusahaan yang Diaudit Oleh KAP Big 4 dan KAP Non Big 4

Perbedaan Relevansi Nilai Earnings \& Book Value of Equity Terhadap Harga Saham Pada Perusahaan yang Diaudit Oleh KAP Terspesialisasi dan KAP Tidak Terspesialisasi

Balsam et al. (2003) menyatakan bahwa kualitas audit yang dihasilkan oleh auditor dengan spesialisasi industri lebih baik dibandingkan dengan kualitas audit yang dihasilkan oleh auditor tidak memiliki spesialisasi audit. Dengan demikian maka laporan keuangan perusahaan yang diaudit oleh auditor yang memiliki spesialisasi dapat katakan lebih baik. Penelitian Dunn, Mayhew, dan Morsfield (2000) juga menyatakan bahwa klien yang diaudit oleh auditor dengan spesialisasi industri memiliki kualitas pengungkapan yang lebih tinggi. Selain itu adanya penelitian lain (Behn et al., 2008) juga menyatakan bahwa kualitas audit yang lebih tinggi dihasilkan oleh auditor non big 5 yang memiliki spesialisasi terhadap industri. Namun pada penelitian yang dilakukan oleh Herusetya (2009) menyatakan bahwa tidak adanya hubungan yang konsisten antara kualitas audit dengan auditor yang memiliki spesialisasi industri. Auditor dikatakan memiliki spesialisasi industri jika auditor tersebut mengaudit $15 \%$ dari total perusahaan yang ada di dalam industri tersebut, sesuai penelitian Craswell, Francis dan Taylor (1995). Berdasarkan penelitian terdahulu tersebut, maka dapat diambil hipotesis sebagai berikut:

$\mathbf{H}_{2}$ : Terdapat Perbedaan Relevansi Nilai Earnings dan Book Value of Equity pada Perusahaan yang Diaudit Oleh KAP dengan spesialisasi industri dan KAP tanpa spesialisasi industri

\section{Metode Penelitian}




\section{Data dan Pemilihan Sampel Penelitian}

Data yang akan digunakan dalam penelitian ini merupakan data atas laporan keuangan atas perusahaan yang terdaftar di dalam Bursa Efek Indonesia (BEI). Data keuangan akan perusahaan tersebut diperoleh me lalui Capital IQ. Sementara itu data kualitas audit didapatkan melalui Capital IQ dan laporan keuangan perusahaan. Laporan keuangan perusahaan sendiri didapatkan melalui IDX dan situs resmi perusahaan. Metode sampling yang digunakan pada penelitian ini sendiri menggunakan metode purposive sampling yang di mana pemilihan sampel penelitian menggunakan kriteria-kriteria atau karakteristik tertentu yang memenuhi kebutuhan dalam melakukan penelitian ini.

\section{Variabel Penelitian dan Definisi Operasional Variabel}

Variabel dependen pada pene litian ini adalah harga saham perusahaan yang diproksikan oleh price stock dan return stock. Untuk price stock digambarkan dengan $P$ dan return stock digambarkan dengan $R$ (Lee \& Lee, 2013). Sedangkan dalam penelitian ini variabel independen dibagi menjadi dua, yaitu variabel earnings dan nilai buku ekuitas. Pada penelitian ini, untuk melihat perbedaan relevansi nilai earnings dan book value of equity terhadap harga saham pada perusahaan yang diaudit oleh KAP Big 4/non-Big 4 dan KAP spesialis/non-spesialis, kami membagi total sampel ke dalam subsampel berdasarkan apakah mereka diaudit oleh KAP Big 4/non-Big 4 dan KAP spesialis/non-spesialis.

\section{Tabel 1}

\section{Definisi Ope rasional Variabel}

\begin{tabular}{|c|c|c|c|}
\hline No & Variabel & Definisi & Pengukuruan \\
\hline 1. & $\begin{array}{c}\text { Dependen: } \\
\bullet \quad \text { Stock Price }\end{array}$ & Harga Saham & 3 bulan setelah periode tutup buku \\
\hline 2. & $\begin{array}{c}\text { Independen: } \\
\text { Pendapatan }\end{array}$ & Earning per Share (EPS) & $\begin{array}{l}\text { (Laba bersih - Div iden preferen) dibagi } \\
\text { dengan rata-rata saham beredar } \\
\text { Total Eku itas dibagi dengan rata-rata } \\
\text { saham beredar }\end{array}$ \\
\hline
\end{tabular}

\section{Model Penelitian}


Dalam penelitian ini, peneliti menggunakan model penelitian yang digunakan oleh Lee dan Lee (2013) dalam mengukur tingkat pengaruh kualitas auditor terhadap relevansi nilai antara pendapatan dan nilai buku ekuitas kepada harga saham perusahaan. Namun di dalam penelitian ini, Peneliti menambahkan proksi dalam mengukur tingkat kualitas audit. Dalam penelitian ini ditambahkan spesialisasi auditor sebagai salah satu pengukur tingkat kualitas audit yang diberikan kepada perusahaan. Model penelitian yang digunakan untuk menguji hipotesis 1 dan hipotesis 2:

Model 1:

$$
R_{i, t}=\alpha_{0}+\alpha_{1} \frac{E_{i, t}}{P_{1, t-1}}+\varepsilon_{1, i, t}
$$

Model 2:

$$
R_{i, t}=\beta_{0}+\beta_{1} \frac{B V S_{i, t}}{P_{1, t-1}}+\varepsilon_{2, i, t}
$$

Model 3:

$$
R_{i, t}=\gamma_{0}+\gamma_{1} \frac{E_{i, t}}{P_{1, t-1}}+\gamma_{1} \frac{B V S_{i, t}}{P_{1, t-1}}+\varepsilon_{3, i, t}
$$

Keterangan:

$R_{i, t} \quad=$ Nilai dari return stock perusahaan

$E_{i, t} \quad=$ Nilai dari earning perusahaan

$B V S_{i, t} \quad=$ Nilai dari nilai buku ekuitas perusahaan

$P_{1, t} \quad=$ Nilai dari Harga saham perusahaan

$\epsilon_{i, t} \quad=$ Eror

$t \quad=1,2, \ldots, \mathrm{T}$ (Tahun)

\section{Metode analisis}

Untuk menguji hipotesis 1 dan 2 langkah-langkah yang dilakukan penulis mengacu kepada penelitian yang dilakukan oleh Lee dan Lee (2013) dengan sebagai berikut: 
1. Melakukan pengelompokan atas sampel yang ada menjadi subsampel yang didasarkan atas auditor big 4 dan non big 4 untuk setiap tahunnya dan pengelompokan berdasarkan KAP terspesialisasi dan non spesialisasi.

2. Kemudian dari subsampel tersebut akan dilakukan regresi untuk mendapatkan $\mathrm{R}^{2}$ dari masing-masing sampel untuk setiap tahunnya.

a. Dalam membandingkan perbedaan relevansi nilai pendapatan perusahaan, maka peneliti menggunakan model 1.

b. Dalam membandingkan perbedaan relevansi nilai pada nilai buku ekuitas perusahaan, maka peneliti menggunakan model 2.

c. Dalam membandingkan perbedaan relevansi nilai pendapatan dan nilai buku ekuitas perusahaan secara bersamaan, maka peneliti akan menggunakan model 3 .

3. Membandingkan nilai dari masing-masing $\mathrm{R}^{2}$ dari setiap subsampel untuk mengetahui perbedaan nilai relevansi.

Setelah didapatkan nilai koefisien determinasi $\left(\mathrm{R}^{2}\right)$ dari masing masing-masing subsampel penelitian, maka akan dilanjutkan pada tahap uji beda. Pada tahap uji beda nilai keofisien deteminasi $\left(\mathrm{R}^{2}\right)$ dari masing-masing subsampel untuk setiap mode lnya akan diuji dengan menggunakan jenis uji beda paired sample t-test dan menggunakan t-test with variable dummy.

\section{Analisis dan Pembahasan}

\section{Data Penelitian}

Penelitian menguji sampel perusahaaan yang terdaftar diantara tahun 2006 sampai dengan tahun 2015. Penelitian ini menggunakan jenis data sekunder yang didapatkan melalui website keuangan Capital Iq dan Yahoo Finance. Populasi dalam penelitian ini adalah perusahaan yang terdaftar pada Bursa Efek Indonesia sampai dengan periode 2015 dengan jumlah perusahaan sebanyak 521. 
Tabel 2

\section{Proses Pemilihan Sampel}

\begin{tabular}{|c|c|}
\hline Keterangan & Juml ah Perusahaan \\
\hline Perusahaan terdaftar pada BEI di akh ir tahun 2015 & 521 \\
\hline \multicolumn{2}{|l|}{$\underline{\text { Kriteria Seleksi Sampel: }}$} \\
\hline 1. Perusahaan industri keuangan & (87) \\
\hline 2. Perusahaan belum terdaftar sa mpai 2006 & $(102)$ \\
\hline 3. Perusahaan delisting & $(80)$ \\
\hline 4. Harga Saham tidak lengkap & $(35)$ \\
\hline 5. Nilai Buku Ekuitas Negatif & (30) \\
\hline Total & 187 \\
\hline
\end{tabular}

Dari tabel dapat kita lihat bahwa perusahaan yang berasal dari industri keuangan sebanyak 87 berdasarkan pengelompokan industri menurut JASICA. Selain itu ada sebanyak 217 perusahaan yang tidak memiliki kelengkapan laporan keuangan selama periode penelitian antara tahun 2006 sampai 2015, yang terdiri dari perusahaan yang belum terdaftar, perusahaan delisting dan harga saham perusahaan tidak lengkap. Terdapat 30 perusahaan yang memiliki nilai buku ekuitas yang negatif. Penelitian tidak memakai perusahaan dengan nilai buku ekuitas negatif dikarenakan penelitian ini dalam menentukan kriteria sampel mengacu kepada penelitian Lee dan Lee (2013). Dengan demikian didapatkan total sampel perusahaan sebanyak 187 perusahaan. Penelitian ini memiliki periode penelitian selama 10 tahun, yaitu antara 2006 sampai 2015 sehingga diperoleh sampel sebanyak 1870 firm-years.

\section{Statistik Deskriptif}

Tabel 3

\section{Statistik Deskriptif Variabel Pe ne litian}

\begin{tabular}{|c|c|c|c|c|}
\hline Variabel & Mean & Std. Dev. & Min & Max \\
\hline $\mathrm{R}$ & 0.0063817 & 0.0984688 & -0.8706688 & 3.019212 \\
\hline $\mathrm{E} / \mathrm{P}$ & 0.1110843 & 0.3949035 & -2.06005 & 7.503892 \\
\hline $\mathrm{BVS} / \mathrm{P}$ & 1.71882 & 2.487144 & 0.0146882 & 35.60945 \\
\hline
\end{tabular}


$\mathrm{R}=$ return saham; $\mathrm{P}=$ Harga saham $; \mathrm{E}=$ earnings per share $; \mathrm{BVS}=$ Book value of equity;

Pada tabel 3 memperlihatkan statistik deskriptif sampel penelitian. Variabel dependen yang digunakan dalam penelitian ini adalah return saham yang tergambarkan melalui R. Selain itu variabel independen yang digunakan adalah earnings per share (EPS), dan book value of equity per share (BVS). Kemudian untuk variabel dummy di dalam penelitian ini adalah kualitas audit (KA) yang diproksikan dengan KAP big 4 dan KAP non big 4 . Untuk perusahaan dengan KAP big 4 akan diberikan nilai 1 sementara perusahaan dengan KAP non big 4 diberikan nilai 0 . Sela in itu variabel dummy yang lain adalah spesialisasi audit (SA) dengan menggunakan proksi KAP spesialisasi dan KAP tanpa spesialiasasi. Untuk perusahaan dengan KAP spesialisasi akan diberikan 1 sementara KAP tanpa spesialisasi akan diberikan 0 .

Mean pada variabel dependen $\mathrm{R}$ berada pada angka 0.0063817atau dapat dikatakan setara dengan $0.6381 \%$. Angka ini menunjukkan bahwa rata-rata perubahan harga saham pada 3 bulan setelah tutup buku dengan harga saham pada sehari sebelumnya tergolong kecil. Tbk pada tahun 2014 dengan -0.8706688 atau setara dengan $-87.06 \%$. Nilai dari variabel independen merupakan hasil pembagian variabel independen dengan harga saham pada 3 bulan setelah tutup buku. Untuk variabel independen E/P nilai tertinggi adalah 7.503892 yang dimiliki oleh PT Indospring Tbk untuk tahun 2010. Sementara itu untuk nilai terendah adalah -2.06005 yang dimiliki oleh PT Sariguna Primatirta Tbk pada tahun 2013. Untuk rata-rata pada E/P adalah sebesar 0.019212. Pada variabel independen BVS/P memiliki rata-rata sebesar 1.71882. Sementara itu PT Indospring Tbk memiliki nilai tertinggi dengan 35.60945 pada tahun 2007. Untuk nilai terendah dimiliki oleh PT Zebra Nusantara Tbk pada tahun 2013 dengan nilai sebesar 0.0146882 .

\section{Uji Hipotesis}

Uji Hipotesis 1 
Tabel 4

Has il Uji Koefisien Determinasi (adj $\mathbf{R}^{2}$ ) untuk Hipotesis 1

\begin{tabular}{|c|c|c|c|c|c|c|}
\hline \multirow{2}{*}{ Year } & \multicolumn{2}{|c|}{ Adj R $\mathbf{R}^{2}$ Model 1 } & \multicolumn{2}{c|}{ Adj R $\mathbf{R}^{2}$ Model 2 } & \multicolumn{2}{c|}{ Adj R ${ }^{2}$ Model 3 } \\
\cline { 2 - 7 } & Big 4 & Non Big 4 & Big 4 & Non Big 4 & Big 4 & Non Big 4 \\
\hline 2006 & -0.0119 & -0.0089 & -0.0043 & -0.0095 & -0.0163 & -0.0188 \\
\hline 2007 & 0.0206 & -0.0046 & -0.0025 & -0.0074 & 0.0363 & -0.0091 \\
\hline 2008 & 0.0924 & -0.0092 & 0.0259 & -0.0094 & 0.0943 & -0.0187 \\
\hline 2009 & 0.0104 & -0.0048 & -0.0126 & -0.0070 & 0.0036 & -0.0101 \\
\hline 2010 & -0.0074 & -0.0083 & 0.0271 & -0.0068 & 0.0140 & -0.016 \\
\hline 2011 & 0.0076 & -0.0053 & -0.0010 & -0.0010 & -0.0018 & -0.003 \\
\hline 2012 & -0.0128 & 0.0012 & -0.0124 & 0.0257 & -0.0256 & 0.0441 \\
\hline 2013 & -0.0093 & -0.0094 & -0.0100 & -0.0080 & -0.0204 & -0.0159 \\
\hline 2014 & -0.0063 & 0.0038 & -0.0101 & 0.0500 & -0.0175 & 0.0562 \\
\hline 2015 & -0.0065 & 0.0120 & 0.0074 & -0.0093 & -0.0015 & 0.0025 \\
\hline Mean & 0.00768 & -0.00335 & 0.00075 & 0.00173 & 0.00651 & 0.0011 \\
\hline
\end{tabular}

Pada pengujian hipotesis 1 ini data dari masing-masing subsampel di-regress untuk didapatkan nilai koefisien determinasi $\left(\mathrm{R}^{2}\right)$ untuk masing-masing model yang akan digunakan untuk melihat tingkat relevansi nilai. Pada uji hipotesis ini pembagian subsampel berdasarkan KAP big 4 dan KAP non big 4. Untuk model 1 digunakan untuk melihat relevansi nilai earnings terhadap return saham. Pada model 2 digunakan untuk mengetahui tingkat relevansi nilai dari book value of equity terhadap return saham. Semantara untuk model 3 melihat relevansi nilai earnings dan book value of equity secara bersama terhadap return saham.

Dari tabel 4 dapat dilihat bahwa pada tahun 2006 sampai dengan 2015 rata-rata koefisien determinasi pada model satu dengan subsampel KAP big 4 dengan variabel earning memiliki nilai yang lebih tinggi, yaitu 0.00768 dibandingkan dengan subsampel yang berasal dari KAP non big 4, yaitu sebesar -0.00335. Di mana angka tersebut memiliki arti bahwa dalam periode penelitian earning dari KAP big 4 dapat menjelaskan $0.768 \%$ terhadap return saham, sementara pada earnings dari KAP non big 4 sebesar $-0.335 \%$ terhadap return saham.Hal ini juga menunjukkan bahwa dalam periode 
penelitian earnings dari subsampel KAP non big 4 tidak memiliki relevansi nilai terhadapreturn saham. Selain itu untuk nilai $R^{2}$ pada subsampel dengan variabel independen book value equity pada KAP big 4 lebih rendah, yaitu sebesar 0.00075 atau sebesar $0.075 \%$, dibandingkan dengan KAP non big 4, yaitu 0.00173 atau $0.173 \%$. Hal ini menunjukkan kemampuan book value of equity dari KAP non big 4 mampu menjelaskan $0.173 \%$ dari return saham dibandingkan KAP big 4 yang hanya sebesar $0.075 \%$. Namun jika digabungkan antara secara bersama antara earnings dengan book value of equity maka nilai koefisien determinasi subsampel KAP big 4 lebih tinggi, yaitu 0.00651 dibandingkan dengan subsampel KAP non big 4, yaitu 0.0011. Hal ini menandakan kemampuan earning dan book value of equity dari KAP non big 4 hanya dapat menjelaskan return saham sebesar $0.651 \%$ dibandingkan dengan KAP big 4 yang hanya sebesar $0.111 \%$.

Jika kita melihat dari persebaran $\mathrm{R}^{2}$ atau koefisien determinasi pada subsampel KAP big 4 dan KAP non big 4 dapat dikatakan pergerakan dari $\mathrm{R}^{2}$ pada masing-masing model bersifat fluktuatif selama periode penelitian. Pada model penelitian 1 menunjukkan $\mathrm{R}^{2}$ dari earnings tergolong rendah. Hal ini menunjukkan bahwa kemampuan dari earning masih rendah dalam menjelaskan return stok. Hal ini juga dapat disebabkan dengan adanya penerapan PSAK 23 yang yang efektif pada tahun 2011 yang kemudian direvisi dan kembali efektif pada tahun 2015. Dengan demikian earnings dari dari perusahaan Indonesia belum dapat maksimal dalam menggambarkan perubahan return saham yang terjadi di pasar.

Tabel 5

Hasil Uji Beda untuk Hipotesis 1

\begin{tabular}{|c|c|c|c|c|c|c|}
\hline & \multicolumn{2}{|c|}{ Model 1} & \multicolumn{2}{|c|}{ Model 2} & \multicolumn{2}{|c|}{ Model 3} \\
\hline & Big 4 & Non Big 4 & Big 4 & Non Big 4 & Big 4 & Non Big 4 \\
\hline \multicolumn{7}{|l|}{ Paired $t$-test } \\
\hline Mean & 0.00768 & -0.00335 & 0.00075 & 0.00173 & 0.00651 & 0.0011 \\
\hline t-stat. & \multicolumn{2}{|c|}{1.0074} & \multicolumn{2}{|c|}{-0.1052} & \multicolumn{2}{|c|}{0.3174} \\
\hline p-value & \multicolumn{2}{|c|}{0.3400} & \multicolumn{2}{|c|}{0.9185} & \multicolumn{2}{|c|}{0.7582} \\
\hline
\end{tabular}




\begin{tabular}{|c|c|c|c|}
\hline t-stat. & -1.0731 & 0.7881 & -0.0575 \\
\hline p-value & 0.2974 & 0.9025 & 0.7087 \\
\hline
\end{tabular}

Tabel 5 menunjukkan hasil uji beda untuk hipotesis 1 . Nilai dari $t$-test pada masing-masing model penelitian menunjukkan tidak terdapat perbedaan yang signifikan pada relevansi nilai baik yang dihasilkan oleh KAP big 4 maupun KAP non big 4. Hal tersebut terlihat dari nilai p-value dari masing-masing subsampel $(0.3400,0.9185$, dan 0.7582$)$ melebihi 0.1 atau batas signifikansi. Hal ini menandakan bahwa tidak adanya perbedaan antara relevansi nilai earnings dan book value of equityyang dihasilkan oleh KAP big 4 dan KAP non big 4.

Kemudian untuk $t$-test dengan variabel dummy yang di mana untuk $R^{2}$ milik KAP big 4akan diberikan nilai 1 sementara $R^{2}$ dari KAP non big 4 akan diberikan nilai 0. Pada uji tersebut juga menunjukkan pada masing-masing model tidak memiliki perbedaan relevansi nilai terhadap return stock yang signifikan untuk masing-masing subsampel. Dengan demikian dapat dikatakan bahwa kualitas audit yang diukur dengan menggunakan ukuran auditor tidak memberikan kontribusi dalam meningkatkan relevansi nilai dari earnings dan book value of equity terhadap return saham.

\section{Uji Hipotesis 2}

Tabel 6

Has il Uji Koefisien De te rminasi $\left(\operatorname{adj} \mathbf{R}^{2}\right)$ untuk Hipotesis 2

\begin{tabular}{|c|c|c|c|c|c|c|}
\hline \multirow{2}{*}{ Year } & \multicolumn{2}{|c|}{ Adj R $\mathbf{R}^{2}$ Model 1 } & \multicolumn{2}{c|}{ Adj R $\mathbf{R}^{2}$ Model 2 } & \multicolumn{2}{c|}{ Adj R Model 3 } \\
\cline { 2 - 7 } & Spesialisasi & Non S pesialisasi & Spesialisasi & $\begin{array}{c}\text { Non } \\
\text { Spesialisasi }\end{array}$ & Spesialisasi & $\begin{array}{c}\text { Non } \\
\text { Spesialisasi }\end{array}$ \\
\hline 2006 & -0.0108 & -0.0091 & -0.0124 & -0.0092 & -0.0237 & -0.0187 \\
\hline 2007 & 0.024 & -0.006 & 0.0005 & -0.0061 & 0.0388 & -0.0092 \\
\hline 2008 & 0.039 & -0.0051 & -0.01 & -0.0088 & 0.0256 & -0.0141 \\
\hline 2009 & -0.0041 & 0.0004 & -0.0131 & -0.0024 & -0.0173 & 0.003 \\
\hline 2010 & 0.0191 & 0.0072 & -0.0114 & 0.0103 & 0.0068 & 0.0089 \\
\hline 2011 & -0.007 & -0.0059 & -0.0048 & -0.0039 & -0.0127 & -0.0055 \\
\hline 2012 & 0.0079 & 0.0301 & -0.0018 & 0.0068 & -0.0032 & 0.0526 \\
\hline 2013 & -0.0122 & -0.008 & -0.0114 & -0.0087 & -0.0232 & -0.0171 \\
\hline
\end{tabular}




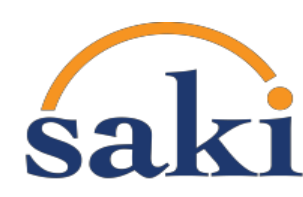

\begin{tabular}{|c|c|c|c|c|c|c|}
\hline 2014 & 0.0178 & -0.004 & -0.0014 & 0.0244 & 0.022 & 0.0187 \\
\hline 2015 & 0.0129 & -0.0048 & -0.0127 & -0.0047 & -0.0016 & -0.0088 \\
\hline Mean & 0.00866 & -0.00052 & -0.00785 & -0.00023 & 0.00115 & 0.00098 \\
\hline
\end{tabular}

Pada tabel 6 dapat terlihat hasil dari pengujian hiposesis 2 dengan menggunakan subsampel KAP dengan spesialisasi dan KAP tanpa spesialisasi. Model 1 menunjukkan bahwa selama periode penelitian relevansi nilai dari KAP terspesialisasi lebih tinggi dengan nilai 0.00866 dibandingkan dengan yang berasal dari KAP tidak terspesialisasi yang sebesar 0.00052. Hal ini menunjukkan bahwa kemampuan earning dalam menjelaskan return saham hanya sebesar $0.866 \%$ dan $-0.052 \%$. Pada model 1 ini juga menunjukkan bahwa earnings dari subsampel KAP tanpa spesialisasi tidak memiliki relevansi nilai terhadap return saham selama periode penelitian. Tingkat koefisien determinasi $\left(\mathrm{R}^{2}\right)$ yang dimiliki oleh subsampel KAP tanpa spesialisasipada model 2 lebih tinggi pada angka -0.00023 dibandingkan dengan subsampel KAP dengan spesialisasi pada nilai -0.00785. Sementara untuk model 3juga menghasilkan hasil yang sama dengan model pertama di mana relevansi nilai dari KAP terspesialisasi lebih tinggi, yaitu 0.00115 sementara relevansi nilai dari KAP tidak terspesialisasi hanya sebesar 0.00098. Hal ini juga menunjukkan bahwa kemampuan earning dan book value of equity dalam menjelaskan return saham hanya sebesar $0.115 \%$ dan $0.098 \%$.

Persebaran dari koefisien determinasi $\left(\mathrm{R}^{2}\right)$ pada hipotesis 2 untuk masing-masing model pada setiap tahunnya dalam periode penelitian dapat dikatakan sangat fluktuatif. Hal ini terlihat dari masing-masing model nilai $\mathrm{R}^{2}$ memiliki tren yang sama dengan $\mathrm{R}^{2}$ pada model dari hipotesis 2 yang juga bersifat fluktuatif selama periode penelitian. 
Tabel 7

Hasil Uji Beda untuk Hipotesis 2

\begin{tabular}{|c|c|c|c|c|c|c|}
\hline & \multicolumn{2}{|c|}{ Model 1} & \multicolumn{2}{|c|}{ Model 2} & \multicolumn{2}{|c|}{ Model 3} \\
\hline & Spesialisasi & $\begin{array}{c}\text { Non } \\
\text { Spesialisasi }\end{array}$ & Spesialisasi & $\begin{array}{c}\text { Non } \\
\text { Spesialisasi }\end{array}$ & Spesialisasi & Non $S$ pesialisasi \\
\hline \multicolumn{7}{|c|}{ Paired $t$-test } \\
\hline Mean & 0.00866 & -0.00052 & -0.00785 & -0.00023 & 0.00115 & 0.00098 \\
\hline t-stat. & \multicolumn{2}{|c|}{1.4791} & \multicolumn{2}{|c|}{-2.4485} & \multicolumn{2}{|c|}{0.0185} \\
\hline $\mathrm{p}$-value & \multicolumn{2}{|c|}{0.1733} & \multicolumn{2}{|c|}{$0.0368 * *$} & \multicolumn{2}{|c|}{0.9856} \\
\hline \multicolumn{7}{|c|}{$t$-test for regression of $R^{2}$ on dummy variable } \\
\hline t-stat. & \multicolumn{2}{|c|}{-1.4078} & \multicolumn{2}{|c|}{1.9867} & \multicolumn{2}{|c|}{-0.0175} \\
\hline p-value & \multicolumn{2}{|c|}{0.1762} & \multicolumn{2}{|c|}{$0.0624^{*}$} & \multicolumn{2}{|c|}{0.9862} \\
\hline
\end{tabular}

Pada tabel 7 dapat terlihat bahwa dua dari tiga model tersebut tidak memiliki perbedaan relevansi nilai untuk masing-masing subsampel pada setiap mode lnya. Hal ini dapat terlihat dari nilai $p$-value yang lebih besar dari 0.1. Untuk model 3 nilai $p$-value mencapai 0.9586 dan untuk model 1 sebesar 0,1733 yang menandakan tidak adanya perbedaan relevansi nilai antar subsampel pada model tersebut. Namun untuk model 2 terdapat perbedaan antara subsampel KAP dengan spesialisasi dan KAP tanpa spesialisasi dengan variabel independen book vaule of equity pada level signifikansi 5\%.

Kemudian untuk t-test dengan variabel dummy yang di mana untuk $R^{2}$ milik KAP dengan spesialisasi akan diberikan nilai 1 sementara $R^{2}$ dari KAP tanpa spesialisasi akan diberikan nilai 0 . Pada uji tersebut juga menunjukkan tren yang sama pada masing-masing model. Hal uji ini menunjukkan dua dari tiga model pene litian, yaitu model 1 dan 3, tidak memiliki perbedaan relevansi nilai terhadap return stock antar subsampel untuk masing-masing model penelitian.Namun pada model 2 terdapat perbedaan antar subsampel pada level signifikansi 10\%. Dengan demikian kualitas audit yang diukur dengan menggunakan spesialisasi auditor juga tidak memberikan kontribusi dalam meningkatkan relevansi nilai dari earnings dan book value of equity terhadap return saham

\section{Pembahasan}


Perbedaan Relevansi Nilai Earnings\&Book Value of Equity Terhadap Harga Saham Pada Perusahaan yang Diaudit Oleh KAP Big 4 dan KAP Non Big

Pada hipotesis pertama dapat mendukung pernyataan Louis (2005) di mana tidak terdapat perbedaan kualitas antara KAP big 4 dan KAP non big 4 . Hal ini dapat terlihat dengan tidak adanya perbedaan pada relevansi nilai untuk ketiga model tersebut. Louis (2005) menyatakan bahwa KAP non big 4 memiliki pengetahuan akan pasar lokal yang baik serta memiliki hubungan yang lebih baik dengan klien mereka dibandingkan dengan KAP big 4.

Hasil tersebut juga didukung oleh penelitian dari Van der Weele (2011) yang menyatakan bahwa kualitas audit tidak memiliki peranan dalam menentukan reaksi pasar. Van der Weele (2011) menyatakan bahwa kualitas audit tidak memiliki dampak pada perusahaan yang juga melakukan restatement atas laporan keuangan mereka. Penelitian dari Dey dan Lim (2014) menyatakan bahwa adanya konsistensi pada peningkatan kualitas audit setelah SOX pada kualitas audit tingkat dua (KAP non big 4) dan bahkan tidak adanya perbedaan dari kualitas audit pada KAP big 4 setelah SOX. Hal ini juga mendukung hasil peneltian ini yang di mana dengan tidak adanya perbedaan kualitas audit antara KAP big 4 dengan KAP non big 4 tergambarkan pada tidak adanya perbedaan relevansi nilai pada earnings dan book value of equity. Dengan demikian pasar tidak lagi melihat peranan kualitas audit pada pergerakan harga saham perusahaan.

Penelitian yang dilakukan Diaz (2009) juga menyatakan bahwa tidak adanya perubahan harga saham pada saat perusahaan mengumumkan perubahan auditor baik dari KAP big 4 ke KAP non big 4 maupun dari KAP non big 4 ke KAP big 4. Dengan demikian dapat dikatakan bahwa pelaku pasar di Indonesia belum me lihat peran auditor di dalam pergerakan harga saham.

Pada hipotesis pertama menunjukkan tidak adanya perbedaan relevansi nilai antara perusahaan yang diaudit oleh KAP big 4 dengan KAP non big 4. Penelitian yang dilakukan Lev dan Zarowin (1999) memperlihatkan penurunan relevansi nilai pada earnings dan book value of equity disebabkan oleh adanya perubahan bisnis serta kesalahan perlakuan akuntansi terhadap perubahan. Di Indonesia sendiri masih dalam tahap pengadopsian standar pelarporan akuntasi internasional (IFRS). 
Sehingga dapat dikatakan relevansi nilai pada laporan keuangan belum maksimal dalam menggambarkan perubahan pada harga saham.

Perbedaan Relevansi Nilai Earnings\&Book Value of Equity Terhadap Harga Saham Pada Perusahaan yang Diaudit Oleh KAP Terspesialisasi dan KAP Tidak Terspesialisasi

Pada hasil hipotesis kedua sejalan dengan hasil penelitian yang dilakukan oleh Herus etya (2009) yang juga menyatakan bahwa tidak ada bukti konsisten yang menunjukkan bahwa kualitas audit dengan spesialisasi auditor. Dengan tidak adanya perbedaan relevansi nilai pada earnings dan book value of equity dari KAP terspesilisasi dengan KAP tidak terspesialisasi dapat dikatakan kualitas audit yang diberikan juga tidak memiliki perbedaan.

Penggunaan persentase aset perusahaan yang diaudit oleh KAP pada suatu industry (Craswell et al., 1995) juga dapat membuat hasil kurang konsisten. Perusahaan dengan aset besar tidak dapat menjamin bahwa perusahaan tersebut memiliki keahlian maupun pangsa pasar yang besar di industri tersebut. Sehingga penggolongan spesialisasi auditor bisa menjadi bias. Dari hasil uji kedua hipotesis tersebut dapat dikatakan bahwa tidak terdapat perbedaan relevansi nilai earnings dan book value equity yang dihasilkan oleh KAP big 4 dan non big 4 . Hal serupa juga terjadi pada relevansi nilai earnings dan book value equity yang dihasilkan KAP dengan spesialisasi dan KAP tanpa spesialisasi.

Selain itu perubahan pada harga saham tidak hanya didasarkan pada performa perusahaan yang tergambarkan di dalam laporan keuangan perusahaan. Banyak faktor-faktor lain di luar laporan keuangan yang mempengaruhi pergerakan harga saham perusahaan. Rjoub, Türsoy, dan Günsel (2009) juga menyatakan bahwa adanya hubungan yang signifikan pada faktor makroekonomi, seperti inflasi, tingkat bunga, dan money supply, terhadap stock return.

Jika hubungkan dengan signaling theory yang menyatakan bahwa kualitas audit sebagai suatu pertanda untuk memberikan sinyal bagi para pelaku pasar. Hasil kedua hipotesis ini menunjukkan bahwa ukuran KAP maupun spesialiasasi auditor memberikan sinyal negatif kepada pelaku pasar. Hal ini terlihat dari tidak terdapatnya perbedaan relevansi nilai pada earnings dan book value equity pada 
perusahaan yang diaudit oleh KAP big 4 dan KAP non big 4 maupun KAP dengan spesialisasi maupun KAP tanpa spesialisasi.

\section{Kesimpulan, Implikasi, dan Keterbatasan}

Dari hasil penelitian yang sudah dilakukan maka dapat ditarik kesimpulan bahwa tidak adanyaperbedaan relevansi nilai earning dan book value of equity pada perusahaan yang diaudit oleh KAP big 4 dan KAP non big 4.Hal ini dapat terlihat dari nilai signifikansi yang berada > 0.1 pada ketiga model penelitian di hipotesis 1 .Semantara pada hipotesis kedua juga menunjukan tidak adanya perbedaan relevansi nilai earning dan book value of equity pada perusahaan yang diaudit oleh KAP dengan spesialisasi dan KAP tanpa spesialisasi.Hal ini dapat terlihat dari nilai signifikansi yang berada $>0.1$ pada ketiga model penelitian di hipotesis 2 .

Hasil penelitian ini mengindikasikan bahwa belum konsisten perbedaaan relevansi nilai yang dari earnings dan book value of equity terhadap return saham pada perusahaan yang diaudit oleh KAP berbeda. Hal ini terutama bagi perusahaan yang diaudit oleh KAP terspesialisasi dan KAP tidak terspesialisasi di mana hasil menunjukkan tidak adanya perbedaan relevansi nilai yang dihasilkan. Hasil penelitian ini diharapkan dapat menjadi pertimbangan bagi akuntan publik untuk dapat meningkatkan kembali kualitas audit yang diberikan, terutama pada KAP dengan spesialisasi.

Pada penelitian ini proksi pengukuran kualitas audit hanya sebatas ukuran KAP dan spesialisasi KAP. Hal ini dikarenakan kedua proksi tersebut merupakan pengukuran yang paling umum digunakan. Untuk penelitian selanjutnya sebaiknya Menggunakan proksi lain dalam menentukan kualitas audit seperti jumlah klien atau tenur audit. Selain itu, pengukuran spesialisasi KAP pada penelitian ini terbatas hanya menggunakan proksi persentase total aset yang diaudit oleh KAP pada suatu industri. Penelitian selanjutnya sebaiknya pengukuran spesialisasi audit dapat menggunakan persentase revenue yang diaudit oleh KAP dalam industri sebagai acuan dasar. 


\section{Daftar Pusaka}

Almutairi, A. R., Dunn, K. A., \& Skantz, T. (2009). Auditor tenure, auditor specialization, and information as ymmetry. Managerial Auditing Journal, 24(7), 600-623.

Balsam, S., Krishnan, J. \& Yang, J.S., 2003. Auditor industry s pecialization and earnings quality. Auditing: A Journal of Practice \& Theory,22(2), pp.71-97.

Barth, M.E., Beaver, W.H. \& Landsman, W.R., 2001. The relevance of the value relevance literature for financial accounting standard setting: another view. Journal of accounting and economics, 31(1), pp.77-104.

Becker, C.L., DeFond, M.L., Jiambalvo, J. \& Subramanyam, K.R., 1998. The effect of audit quality on earnings management. Contemporary accounting research, 15(1), pp.1-24.

Behn, B.K., Choi, J.H. \& Kang, T., 2008. Audit quality and properties of analyst earnings forecasts. The Accounting Review, 83(2), pp.327-349.

Be island, L.A., 2009. A review of the value relevance literature. The Open Business Journal, 2(1), pp.7-27.

Carey, P. \& Simnett, R., 2006. Audit partner tenure and audit quality. The accounting review, 81(3), pp.653676.

Chang, X., Dasgupta, S. \& Hilary, G., 2009. The effect of auditor quality on financing decisions. The Accounting Review, 84(4), pp.1085-1117.

Chandrapala, P., 2013. The value relevance of earnings and book value: The Importance of ownership concentration and firm size. Journal of Competitiveness, 5(2), pp.98-107.

Chi, W. \& Huang, H., 2005. Discretionary accruals, audit-firm tenure and audit-partner tenure: Empirical evidence from Taiwan. Journal of Contemporary Accounting \& Economics, 1(1), pp.65-92.

Craswell, A.T., Francis, J.R. \& Taylor, S.L. (1995). Auditor Brand Name Reputation and Industry Specialization. Journal of Accounting and Economics, 20, 297-322.

Diaz, M. (2009). Analisis Reaksi Pasar Terhadap Pengumuman Pergantian Kantor Akuntan Publik. Jurnal Simposium Nasional Akuntansi XIII.

Dopuch, N., King, R.R. \& Schwartz, R., 2003. Independence in appearance and in fact: An experimental investigation. Contemporary Accounting Research, 20(1), pp.79-114.

Dey, R. M., \& Lim, L. S. (2014). Audit Quality of Second-Tier Auditors: Are All Created Equally. The BRC Academy Journal of Business, 4(1), 1-26.

Dunn, K., Mayhew, B., \& Morsfield, S. (2000), ”Auditor Industry Specialization and Client D isclosure Quality”, http://www.papers.ssrn. com/diakses 18 Januari 2015.

Hakim, F., \& Omri, M. A. (2010). Quality of the external auditor, information asymmetry, and bid-ask spread: case of the listed Tunisian firms. International Journal of Accounting \& Information Management, $18(1), 5-18$.

Herusetya, A., 2009. Pengaruh ukuran auditor dan spesialisasi auditor terhadap kualitas laba. Jurnal Akuntansi dan Keuangan Indonesia, 6(1), pp.46-70.

Hidayat, T., 2012. Pengaruh Ukuran KAP dan Auditor Tenure Terhadap Va lue Relevance dari Nilai Wajar. Jurnal Akuntansi dan Keuangan Indonesia, 9(2), pp.171-188.

Jensen, Michael C., and William H. Meckling. "Theory of the firm: Managerial behavior, agency costs and ownership structure." Journal offinancial economics 3.4 (1976): 305-360.

Lee, H.L. \& Lee, H., 2013. Do Big 4 audit firms improve the value relevance of earnings and equity?. Managerial Auditing Journal, 28(7), pp.628-646.

Lev, B., \& Zarowin, P. (1999). The boundaries of financial reporting and how to extend them. Journal of Accounting research, 37(2), 353-385.

Louis, H. (2005). Acquirers' abnormal returns and the non-Big 4 auditor clientele effect. Journal of Accounting and Economics, 40(1), 75-99.

Otoritas Jasa Keuangan. (2016). Peraturan Otoritas Jasa Keuangan Nomor 29/POJ K.4/2016 tentang Laporan Tahunan Emiten atau Perusahaan Publik. Jakarta: Percetakan Pemerintahan Indonesia. 
Rjoub, H., Türsoy, T., \& Günsel, N. (2009). The effects of macroeconomic factors on stock returns: Istanbul Stock Market. Studies in Economics and Finance, 26(1), 36-45.

Teoh, S.H. \& Wong, T.J., 1993. Perceived auditor quality and the earnings response coefficient. Accounting Review, pp.346-366.

Van der Weele, M. L. (2011). Restatement announcements: the effect of audit quality on the market reaction.

Watts, R. L., \& Zimmerman, J. L. (1986). Positive Accounting Theory. Contemporary Topics in Accounting Series. 